\title{
Preserving Slave Families for Profit: Traders' Incentives and Pricing in the New Orleans Slave Market
}

\author{
Charles W. Calomiris And Jonathan B. Pritchett
}

\begin{abstract}
We investigate determinants of slave family discounts in the New Orleans slave market. We find large price discounts for families unrelated to scale effects, childcare costs, legal restrictions, or transport costs. We posit that because family members voluntarily cared for each other, sellers sometimes found it advantageous to keep families together (when families included needy or dependent members). Evidence from ship manifests carrying slaves for sale in New Orleans provides direct evidence for selectivity bias in explaining slave family discounts. Children likely to have been shipped with their mothers are 1 to 2 inches shorter than other children.
\end{abstract}

Since the publication of Robert W. Fogel and Stanley L. Engerman's Time on the Cross, economic historians have been actively debating the validity of one of their central propositions - that slaves were allowed, and encouraged, to maintain family ties because doing so enhanced the value of slaves to their owners. Laurence Kotlikoff investigated the potential effect of family connections on the value of slaves sold in the New Orleans market at the time of their sale. ${ }^{1}$ If preserving family ties enhanced the value of slaves to their owners, as Fogel and Engerman posited, the value of slave family members sold together would be higher. Kotlikoff found that the value of motherfather-child groups - a rare event in the data - was higher than the combined value of the members of the family if they were sold singly. However, other family combinations, including mother-child sales-by far the most common form of family sale-suffered large discounts when compared to the sales of identical family members sold separately.

Fogel and Engerman argued that this finding could reflect a scale discount associated with slave sales - by selling the slaves as a group

The Journal of Economic History, Vol. 69, No. 4 (December 2009). (C) The Economic History Association. All rights reserved. ISSN 0022-0507.

Charles W. Calomiris is the Henry Kaufman Professor of Financial Institutions, Columbia Business School, Columbia University, 3022 Broadway, Uris Hall 601, New York, NY 10027. E-mail: cc374@columbia.edu. Jonathan B. Pritchett is Associate Professor, Department of Economics, 206 Tilton Hall, Tulane University, New Orleans, LA 70118. E-mail: jprit@tulane.edu.

The authors thank Rick Steckel for sharing his data on ship manifests, and received helpful comments from Jonah Rockoff, Stan Engerman, Bob Margo, Price Fishback, two anonymous referees, and participants in the NBER Development of the American Economy Program Meeting, March 2, 2008.

${ }^{1}$ Kotlikoff, "Structure" and "Quantitative Description." 
rather than singly, the sum of transactions costs would be reduced, or equivalently, buyers would realize a scale discount. ${ }^{2}$ If the discount outweighed the economic benefits associated with family ties, family members would sell at a discount rather than a premium. If that explanation were correct, it could be confirmed by empirical analysis of two questions: (1) Is there a scale discount for selling slaves irrespective of whether they are family members or not; and (2) Do slave groups of any particular size command higher market prices when the members of the group sold are family members (as opposed to unrelated group members)? To our knowledge, no one has investigated these questions empirically.

A related issue is the need to consider the potential effect of selectivity bias in the slave sales process. Slaves who are sold are likely not a random sample of slaves in the population. In addition, it is possible that slave family members sold together are selected for sale through a different process than slaves sold individually. If that were true, then the family discount observed in the sales of slave family groups might reflect differences in the selection process for the sale of families compared to the selection process for the sale of individuals. If selectivity bias explains the family discount, then observed discounts may give a distorted measure of the underlying value (in the broader slave population) to masters of keeping slave families together.

Independent of their owners' economic interests, families would not exist without the active support and participation of the slaves themselves. The family served, among other things, as a form of longterm life insurance against the hardships of slavery. Owners sometimes may have benefited from this mutual dependency by selling family members together rather than singly. Most obviously, if one member of the group were weak or sick, that individual might be sold with another member of his family because the joint value of the two would be greater than their value if sold separately. This negative selection of family groups would produce a family discount, which is simply indicative of the lower market price attached to the weak, sick, or needy member of the family group.

Transport costs may have affected the average value of slaves shipped in family groups versus the value of slaves shipped singly. When a fixed transport cost is applied to two similar goods, the effect is to lower the relative price of the higher quality good. Because shipment of slaves was costly, the relative price of high-valued slaves was lower in New Orleans, and as a consequence, buyers preferred to purchase relatively more

\footnotetext{
${ }^{2}$ Fogel and Engerman, "Some Notes," p. 258.
} 
of them. Positive selection is likely to have its greatest effect on the attributes of children chosen for market - only the healthiest and most robust would justify the cost of shipment. ${ }^{3}$ In deciding whether to ship a family to New Orleans, a trader would consider the attributes of the entire family, not just those of the children. It is possible that the children shipped with families were less rigorously selected than the children shipped singly. In addition, it might have been cheaper to ship a child with a parent rather than by himself. If that were true, then the selection produced by transport costs for the attributes of family members could be different from those of individuals.

Legal restrictions could also have played a role in producing observed price differences between family group members and stand-alone slaves. Children under the age of ten could not be legally sold alone unless they were orphans. Also, superannuates were legally required to be sold jointly with a child (if one were present). If these Louisiana laws were enforced, that may have reduced the market value of slaves sold as part of family groups.

We test these various explanations of group scale discounts, and family-ties premia or discounts, using prices for slaves sold in the New Orleans market from 1820 through 1860. We distinguish sales of groups that include family and nonfamily members, and family group sales of different types (those involving small children, and other sales), to investigate how family-ties premia or discounts vary with the structure of the family sold. Our results from slave price regressions lend support to the view that selectivity bias involving family groups, rather than economies of scale in selling, explains the observed group discounts.

Absent scale discounts, the fact that family groups sold at discount suggests that slave owners benefited from preserving families when those family members had relatively low stand-alone market values. Otherwise, in the absence of an economic benefit, sellers could have increased their profit by separating families at the time of sale. Stated differently, under the assumption of zero arbitrage profits, the fact that heavily discounted family group sales occurred provides evidence of selectivity bias, which reflected the voluntary provision of care among slave family members. Slave owners' decisions not to separate families despite a family discount indicated that they perceived that the sum of the stand-alone prices they would have received by separating families would have been lower than the discounted family group sale price, presumably because of the assistance and care that family members voluntarily provided one another.

\footnotetext{
${ }^{3}$ Alchian and Allen, Exchange and Production, pp. 78-79; Pritchett and Chamberlain, "Selection"; and Pritchett and Freudenberger, "Peculiar Sample."
} 
In the case of family groups involving parent-child relationships, one can gauge the potential importance of selectivity bias by examining additional data. We examine data from ship manifests on the heights of slave children during their transport for sale to the New Orleans slave market. We find that children traveling as members of family groups are substantially shorter (by roughly two inches) than children of the same age and sex that we identify as traveling separately. We argue that the taller stature of children shipped without parents provides further evidence that some form of selectivity by traders explains the familyties discounts observed in the New Orleans slave market. We find that transport costs resulted in higher values for imported slaves, but the size of group family discounts is unrelated to whether a slave is imported or not. We find some evidence for the role of legal restrictions in boosting family discounts (after legal changes in 1829), but legal factors cannot explain most of our findings.

\section{MODELING SLAVE PRICES FROM NEW ORLEANS SALES}

We use the New Orleans Slave Sale Sample, originally collected under the direction of Fogel and Engerman, and used previously by Kotlikoff, Bruce Greenwald and Robert Glasspiegel, Herman Freudenberger and Pritchett, and Eugene Choo and Jean Eid. ${ }^{4}$ During the first part of the nineteenth century, New Orleans was the center of slave trading in the South. Transactions included both local slave sales and sales of imported slaves, often brought by ship from elsewhere in the South. Because of its French legal tradition, slaves in Louisiana were considered real estate rather than personal property, and as such, all slave sales had to be notarized. ${ }^{5}$ The Fogel and Engerman slave sale sample was drawn from the New Orleans Notarial Archives, which was created in 1867 to serve as a depository of the notarial records. These records are not a complete set of transactions - some notarial records were destroyed in office fires, whereas others were simply lost. Depending on the year of sale, between 2.5 and 5 percent of the extant notarial records comprise the sample of slave sales recorded by Fogel and Engerman.

The sample contains 2,169 usable observations of stand-alone sales of slaves, which we define as transactions in which only one slave was sold. The data set also contains 683 usable group sale transactions. Recorded

\footnotetext{
${ }^{4}$ Fogel and Engerman, "New Orleans Slave"; Kotlikoff, "Structure" and "Quantitative Description"; Greenwald and Glasspiegel, "Adverse Selection"; Freudenberger and Pritchett, "Domestic"; and Choo and Eid, "Interregional Price Difference."

${ }^{5}$ Louisiana, Acts Passed, p. 101. For a few sales, slave titles were transferred under the private signatures and witnessed by a judge, rather than recorded by a public notary.
} 
characteristics of the individuals in the group include their age, sex, and family relationship (although it is possible that family relationships were not always noted). Other data fields include information about the degree of skin darkness, whether the transaction was for cash or credit, and whether the slaves were sold with a guarantee. ${ }^{6}$ Prices are normalized, as in Kotlikoff, by dividing the observed price by the average price of a male, aged 21 to 38 years, sold in that same year. This procedure avoids the need to control for price changes over time.

Before discussing our approach to modeling the factors that affected the pricing of slave groups, it is useful to review some of the differences between the samples of stand-alone and group transactions, and the frequency of different types of groups. Such information offers important hints about potential selectivity in the determination of whether a slave was included in a group or stand-alone transaction, or a particular type of group transaction.

Most obviously, the age distributions are very different for the standalone and group samples. The group sample includes more children, especially young ones. Children younger than ten represent 3 percent of stand-alones and nearly 29 percent of group sales. Legal restrictions may have reduced the number of children under the age of ten years sold without their parent. Additional legal restrictions applied to the separate sale of weak or sick slaves, who are more frequently elderly. In addition, differences in the age distributions may reflect different economic advantages from preserving familial relationships for slaves of different ages.

Relatively few intact families were sold in New Orleans and most family groups were comprised of mothers with children. Family group members accounted for 45 percent of the total number of slaves sold in groups. Most family group members ( 87 percent) consisted of mothers and their children, and the most common family group consisted of a mother with children (90 percent). Mother-father-child groups were rare (only 3.6 percent of the total number of family groups). Other adult family affiliations (by which we mean other family groupings in which children age 13 and younger were not present) took the form of husband-wife pairs and sibling groupings.

We construct a model of stand-alone slave sales to serve as our benchmark for group sales. The stand-alone model can be used to generate predicted values for each group sale by adding together the

\footnotetext{
${ }^{6}$ According to the law, slaves were sold with an implied guarantee against "physical or moral defects," unless the contract specifically limited that guarantee. So-called moral defects included drunkenness or the propensity to attempt escape.

${ }^{7}$ Kotlikoff, "Structure" and "Quantitative Description."
} 
predicted values of each group member to create a composite predicted value for the group. ${ }^{8} \mathrm{We}$ then predict group discounts or premia, defined as the logarithm of the difference of the actual and predicted group price, using the characteristics of the group.

First, we estimate a stand-alone model that regresses observed standalone prices on a variety of slave characteristics. This model is a modification of Kotlikoff's pricing model, which includes the regressors listed in Table 1. The most important difference between our standalone model and Kotlikoff's model arises because we apply the Kotlikoff model only to stand-alone transactions. Kotlikoff included mother-child transactions in his model, while we model them separately in our group transactions analysis. In other respects, however, our model is very close to Kotlikoff's. We experimented with a variety of alternative specifications for the age-sex distribution and found that none of them substantially improved the fit of the stand-alone model. In response to a suggestion from Engerman, we added indicator variables that capture whether slave buyers or slaves were from New Orleans. We found that this addition improved the fit of both the stand-alone and group regression models, but does not affect other results.

Table 1 reports the estimation results for our stand-alone version of the Kotlikoff model. The results are familiar. Males are worth more. Light skin adds some market value for females, but not for males. Guarantees raise prices. Transactions that involve credit require higher prices. The effect of age is estimated by a six-order polynomial. The prices of men and women peak in their early 20s, and values drop dramatically in the late $30 \mathrm{~s}$ and $40 \mathrm{~s}$. The residuals from the standalone regression are similar across the range of slave ages in the sample. In particular - and importantly for our discussion below of group sales regressions - the regression does not over predict the prices of standalone children or superannuates.

\section{GROUP SALES REGRESSIONS}

We turn now to the group sales regressions. The dependent variable is the "group premium," defined as the logarithm of the difference between the actual group price and the sum of the predicted standalone prices for the group members, using the coefficients from Table 1 to generate predicted prices for each group member. We investigate the effects of several potential influences in producing predictable

\footnotetext{
${ }^{8}$ We adjust the predicted values to account for the lognormal variance. See Greene, Econometric Analysis, p. 299.
} 
TABLE 1

NEW ORLEANS SLAVE PRICE STRUCTURE, INDIVIDUAL SALES REGRESSION COEFFICIENTS, MEANS, AND STANDARD DEVIATIONS

\begin{tabular}{|c|c|c|}
\hline Covariate & $\begin{array}{l}\text { Regression } \\
\text { Coefficient }\end{array}$ & $\begin{array}{l}\text { Mean and } \\
\text { Std. Dev. }\end{array}$ \\
\hline Slave price relative to prime-aged male & & $\begin{array}{c}0.799 \\
(0.318)\end{array}$ \\
\hline Intercept & $\begin{array}{l}-2.381 \\
(0.144)\end{array}$ & 1.000 \\
\hline Male $(1=$ yes, $0=$ no $)$ & $\begin{array}{l}0.143^{*} \\
(0.037)\end{array}$ & $\begin{array}{l}0.470 \\
(0.499)\end{array}$ \\
\hline Light-colored female $(1=$ yes, $0=$ no $)$ & $\begin{array}{l}0.047^{*} \\
(0.023)\end{array}$ & $\begin{array}{c}0.133 \\
(0.339)\end{array}$ \\
\hline Light-colored male $(1=$ yes, $0=$ no $)$ & $\begin{array}{l}0.025 \\
(0.026)\end{array}$ & $\begin{array}{l}0.100 \\
(0.300)\end{array}$ \\
\hline Male sold with guarantee $(1=$ yes, $0=$ no $)$ & $\begin{array}{l}0.301^{*} \\
(0.027)\end{array}$ & $\begin{array}{l}0.377 \\
(0.485)\end{array}$ \\
\hline Female sold with guarantee $(1=$ yes, $0=$ no $)$ & $\begin{array}{l}0.297 * \\
(0.029)\end{array}$ & $\begin{array}{c}0.455 \\
(0.498)\end{array}$ \\
\hline $\begin{array}{l}\text { Months of credit extended, equals } 0 \text { if interest } \\
\text { charged }\end{array}$ & $\begin{array}{l}0.015^{*} \\
(0.002)\end{array}$ & $\begin{array}{l}1.803 \\
(4.805)\end{array}$ \\
\hline Female with household occupation $(1=$ yes, $0=$ no $)$ & $\begin{array}{c}0.042 \\
(0.034)\end{array}$ & $\begin{array}{c}0.052 \\
(0.221)\end{array}$ \\
\hline Male with household occupation $(1=$ yes, $0=$ no $)$ & $\begin{array}{c}0.011 \\
(0.061)\end{array}$ & $\begin{array}{c}0.014 \\
(0.119)\end{array}$ \\
\hline $\begin{array}{l}\text { Occupation other than artisan or household work } \\
(1=\text { yes, } 0=\text { no })\end{array}$ & $\begin{array}{l}-0.014 \\
(0.073)\end{array}$ & $\begin{array}{l}0.010 \\
(0.100)\end{array}$ \\
\hline Skilled worker, aged 15 to 25 years $(1=$ yes, $0=$ no $)$ & $\begin{array}{c}0.220^{*} \\
(0.097)\end{array}$ & $\begin{array}{l}0.006 \\
(0.074)\end{array}$ \\
\hline Skilled worker, aged 26 to 30 years $(1=$ yes, $0=$ no $)$ & $\begin{array}{l}0.305^{*} \\
(0.102)\end{array}$ & $\begin{array}{l}0.005 \\
(0.071)\end{array}$ \\
\hline Skilled worker, aged 31 to 40 years $(1=$ yes, $0=$ no $)$ & $\begin{array}{l}0.535^{*} \\
(0.128)\end{array}$ & $\begin{array}{l}0.003 \\
(0.057)\end{array}$ \\
\hline Skilled worker, aged 41 to 60 years $(1=$ yes, $0=$ no $)$ & $\begin{array}{l}0.441^{*} \\
(0.153)\end{array}$ & $\begin{array}{c}0.002 \\
(0.048)\end{array}$ \\
\hline Sold in January $(1=$ yes, $0=$ no $)$ & $\begin{array}{c}0.119 * \\
(0.041)\end{array}$ & $\begin{array}{c}0.112 \\
(0.316)\end{array}$ \\
\hline Sold in February $(1=$ yes, $0=$ no $)$ & $\begin{array}{c}0.053 \\
(0.042)\end{array}$ & $\begin{array}{c}0.096 \\
(0.295)\end{array}$ \\
\hline Sold in March $(1=$ yes, $0=$ no $)$ & $\begin{array}{c}0.082^{*} \\
(0.041)\end{array}$ & $\begin{array}{c}0.114 \\
(0.318)\end{array}$ \\
\hline Sold in April $(1=$ yes, $0=$ no $)$ & $\begin{array}{c}0.100^{*} \\
(0.041)\end{array}$ & $\begin{array}{c}0.118 \\
(0.322)\end{array}$ \\
\hline Sold in May $(1=$ yes, $0=$ no $)$ & $\begin{array}{c}0.035 \\
(0.041)\end{array}$ & $\begin{array}{c}0.116 \\
(0.320)\end{array}$ \\
\hline
\end{tabular}

group premia or discounts. We present weighted least squares results, weighted by group size, in Table 2. Larger groups should have smaller group error terms because of the law of large numbers. We find, indeed, 
TABLE $1-$ continued

\begin{tabular}{|c|c|c|}
\hline Covariate & $\begin{array}{l}\text { Regression } \\
\text { Coefficient }\end{array}$ & $\begin{array}{l}\text { Mean and } \\
\text { Std. Dev. }\end{array}$ \\
\hline Sold in June $(1=$ yes, $0=$ no $)$ & $\begin{array}{c}0.019 \\
(0.043)\end{array}$ & $\begin{array}{c}0.082 \\
(0.274)\end{array}$ \\
\hline Sold in July $(1=$ yes, $0=$ no $)$ & $\begin{array}{c}0.026 \\
(0.044)\end{array}$ & $\begin{array}{c}0.068 \\
(0.252)\end{array}$ \\
\hline Sold in August $(1=$ yes, $0=$ no $)$ & $\begin{array}{c}0.080^{*} \\
(0.046)\end{array}$ & $\begin{array}{c}0.058 \\
(0.234)\end{array}$ \\
\hline Sold in October $(1=$ yes, $0=$ no $)$ & $\begin{array}{c}0.063 \\
(0.045)\end{array}$ & $\begin{array}{c}0.065 \\
(0.247)\end{array}$ \\
\hline Sold in November $(1=$ yes, $0=$ no $)$ & $\begin{array}{c}0.076^{*} \\
(0.045)\end{array}$ & $\begin{array}{c}0.061 \\
(0.240)\end{array}$ \\
\hline Sold in December $(1=$ yes, $0=$ no $)$ & $\begin{array}{c}0.110^{*} \\
(0.045)\end{array}$ & $\begin{array}{c}0.067 \\
(0.251)\end{array}$ \\
\hline Age in years & $\begin{array}{c}0.190^{*} \\
(0.038)\end{array}$ & $\begin{array}{c}24.34 \\
(10.23)\end{array}$ \\
\hline $\mathrm{Age}^{2} \cdot 10^{-2}$ & $\begin{array}{c}-0.542 \\
(0.427)\end{array}$ & $\begin{array}{l}6.97 \\
(6.07)\end{array}$ \\
\hline $\mathrm{Age}^{3} \cdot 10^{-3}$ & $\begin{array}{c}-0.037 \\
(0.225)\end{array}$ & $\begin{array}{c}22.99 \\
(31.88)\end{array}$ \\
\hline $\mathrm{Age}^{4} \cdot 10^{-4}$ & $\begin{array}{c}0.004 \\
(0.060)\end{array}$ & $\begin{array}{c}85.42 \\
(169.39)\end{array}$ \\
\hline $\mathrm{Age}^{5} \cdot 10^{-5}$ & $\begin{array}{c}-0.0017 \\
(0.0076)\end{array}$ & $\begin{array}{c}349.43 \\
(937.78)\end{array}$ \\
\hline $\mathrm{Age}^{6} \cdot 10^{-6}$ & $\begin{array}{c}-0.00015 \\
(0.00037)\end{array}$ & $\begin{array}{c}1544.27 \\
(5443.40)\end{array}$ \\
\hline Buyer from New Orleans $(1=$ yes, $0=$ no $)$ & $\begin{array}{l}-0.108^{*} \\
(0.029)\end{array}$ & $\begin{array}{c}0.780 \\
(0.414)\end{array}$ \\
\hline Slave from New Orleans $(1=$ yes, $0=$ no $)$ & $\begin{array}{l}-0.050 \\
(0.031)\end{array}$ & $\begin{array}{c}0.708 \\
(0.455)\end{array}$ \\
\hline Buyer and slave from New Orleans $(1=$ yes, $0=$ no $)$ & $\begin{array}{c}0.072 * \\
(0.036)\end{array}$ & $\begin{array}{c}0.580 \\
(0.494)\end{array}$ \\
\hline Adjusted $R^{2}$ & 0.484 & \\
\hline Number of observations & \multicolumn{2}{|c|}{2169} \\
\hline
\end{tabular}

*indicates the regression coefficient is statistically different from zero at the 10 percent level. Notes: The dependent variable is the logarithm of the slave's price relative to the average annual price of a male slave, aged 21 to 38 years. Sample includes New Orleans slaves sold singly. The omitted variable refers to unguaranteed dark-colored females, without a reported skill, sold for cash in September. Standard errors are listed in parentheses beneath regression coefficients.

Source: Fogel and Engerman, "New Orleans Slave."

that larger groups have smaller error terms. We also ran regressions using heteroskedasticity correction to control for differences in errors across groups, and found very similar results. Also, ordinary least squares regressions (not reported here) are qualitatively very similar to the results in Table 2 . 


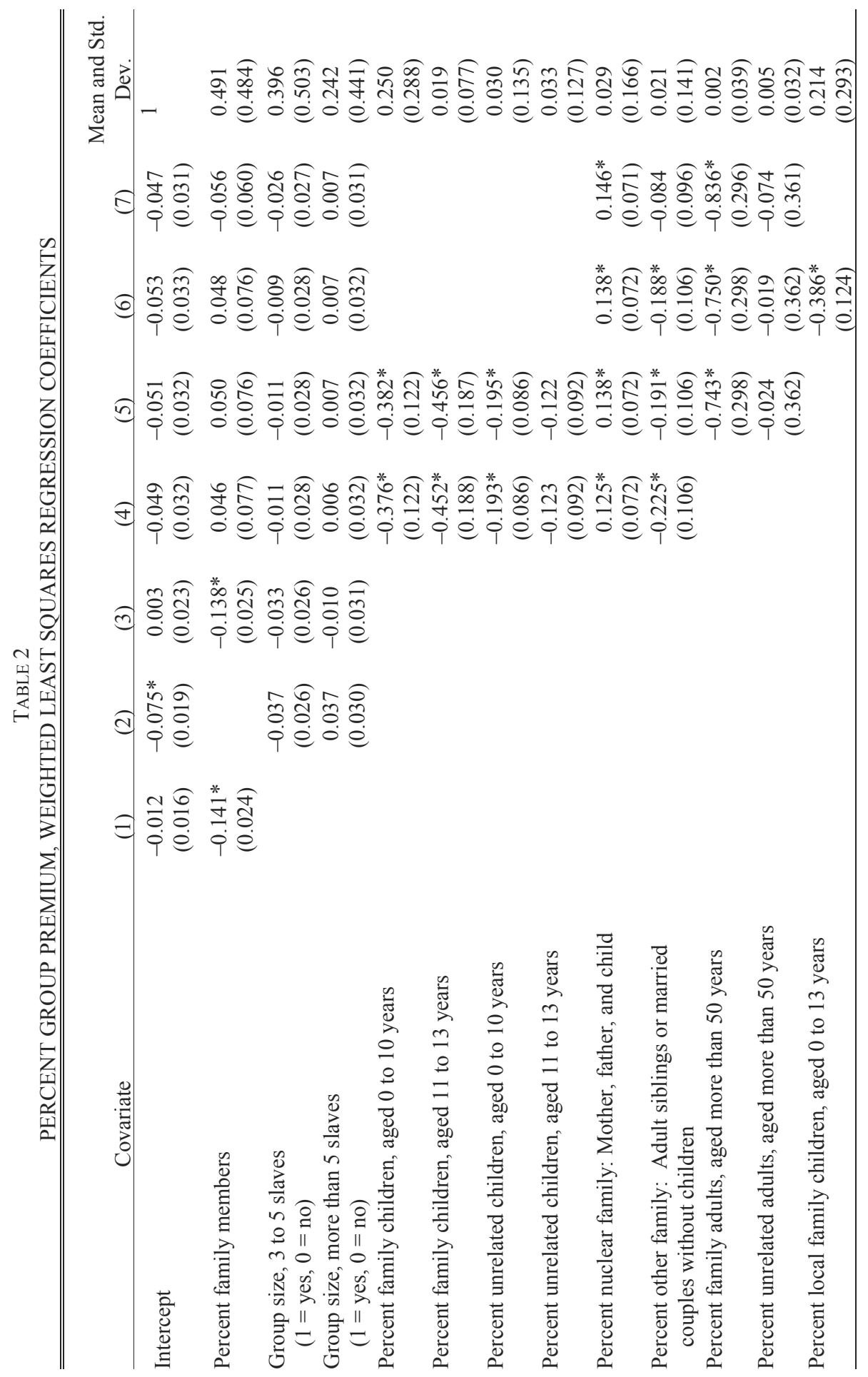




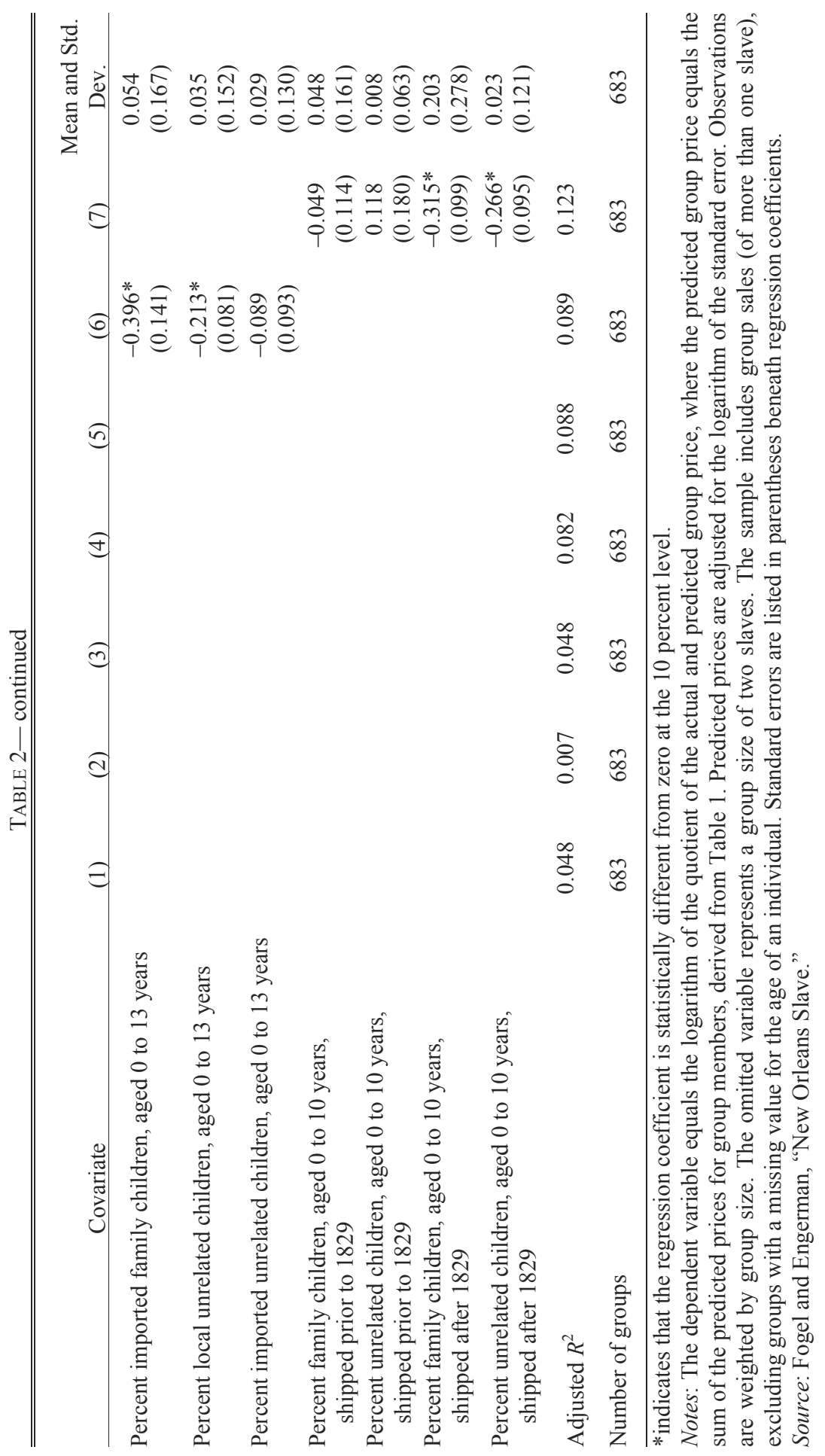




\section{Scale and Group Discounts}

Fogel and Engerman hypothesized that the size of the group sold may lead to differences in pricing if larger transactions enjoy scale discounts. ${ }^{9}$ We investigate this hypothesis by dividing our group sample into three groups by size: groups of two people, groups of three-five people, and groups of more than five people. Finer divisions of the sample, or alternative specifications of size effects yield similar results to those reported in Table 2 and are not reported here.

Equation 2, located in Table 2, provides the simplest version of a regression testing for scale effects in the group premium. Groups of two people are contained in the intercept, and indicator variables are included for group sizes of three to five and over five. The three coefficient estimates indicate that statistically significant group discounts averaging 7.5 percent are present for groups of two people; for groups of three-five people, discounts average 11.2 percent and are statistically significant; and groups of more than five people display a 3.8 percent average discount, which is not statistically different from zero at the 10 percent significance level. Equation 2, therefore, suggests the opposite of a scale discount for group sales, since larger groups command a lower discount.

Once one controls for the family and age structure of groups, the scale premium observed in equation 2 disappears. Equation 3 adds the percentage of group members that are related as family members to the group size indicators, and equations 4 and 5 add variables that capture the structure of family and nonfamily groups. ${ }^{10}$ When these variables are added, the intercept and the two group size indicator variables become small and are no longer statistically significant.

\section{Families, Group Structure, and Group Discounts}

The specific structure of the family group is crucial for understanding the size of the family discount. The estimated coefficients for children sold in family groups are large, negative, and range between -0.38 and -0.45 . The coefficient of -0.376 for the percent of related children aged 0 to 10 implies that the discount for a four-person family group with two parents and two young children under 10 was 0.188 , which is derived by multiplying the 0.5 share of related children under age ten by

\footnotetext{
9 "Some Notes."

${ }^{10}$ Both related and unrelated individuals were sometimes sold together. Consequently, we indicate the presence of related individuals in the group as a percentage of the total group size rather than use a simple dummy variable.
} 
the coefficient of 0.376 . This discount is consistent with the earlier findings of Kotlikoff and Fogel and Engerman, which they interpreted incorrectly as a scale effect. ${ }^{11}$

Interpretations of the coefficients for the shares of unrelated children of different age groups are clouded by the possibility that some sales records may not have accurately recorded all parent-child affiliations. The results in Table 2 show that there were discounts for unrelated children in the group, but this may be due to measurement error. Suppose that the presence of unrelated children had no effect on the size of the group discount. If the effect of kids related to parents in the group is negative, and if many children that are coded as unrelated are really related to a parent in the group, that could lead us to observe a negative coefficient for the unrelated children share. In that case, the coefficient for the unrelated children would be less negative than the one for related children, which is precisely what we find in equation 4 . The coefficient on unrelated children ages $0-10$ is -0.193 , is statistically significant, and is half the magnitude of the coefficient on related children of the same age. Similarly, the coefficient on unaffiliated children ages $11-13$ is -0.123 and much smaller than the analogous coefficient for related children (-0.452), although it is not statistically significant. One interpretation of these results is that many of the children under the age of 11 that were not recognized in the written record of the transaction as affiliated were in fact affiliated, but that this was less likely for children of ages 11-13.

Should one interpret discounts associated with children as reflecting childcare costs? We believe that would not be a proper interpretation of these coefficients, for three reasons. First, observed family discounts were not just on infants or toddlers (those with the highest childcare costs), but are present for children ranging up to 13 years of age, and these discounts are roughly identical for children of all ages within that range; in fact, the estimated discounts are most negative for the 11-13 age range. Second, young children sold on a stand-alone basis also required significant childcare from someone, and thus some discount for childcare costs should have been priced into all child sales, irrespective of whether children were sold on a stand-alone basis or with a relative. Third, as we explore more fully below, family group sales other than those involving parent-children groupings also display large group discounts, which could not possibly reflect childcare costs. This suggests a more general explanation for family discounts that would apply to discounts associated with children as well as other

\footnotetext{
${ }^{11}$ Kotlikoff, "Structure," p. 513; and Fogel and Engerman, "Some Notes," p. 258.
} 
family members. The most obvious explanation, which we confirm with additional evidence below, is selectivity bias related to the value of preserving the voluntary provision of care among family members. Children not sold in family groups (a relatively infrequent event) may have been exceptional in their level of physical, emotional, or mental maturity.

Only 12 groups in our sample contain a nuclear family of mother, father, and at least one child. The total premium effect for the nuclear family is measured as the coefficient on the nuclear family variable plus the share of children in each age group times the coefficient for that agent group. For example, a family of three sold together, comprised of a father, mother, and a 10-year-old girl, would show the following total group premium effect: $(0.13)+(0.33)(-0.37)$. While the nuclear family coefficient itself is positive, of a reasonably high magnitude, and statistically significant, the total group premium effect for a group consisting of a father, mother, and 10-year-old girl is essentially zero. We interpret this zero effect as the sum of a negative effect from selectivity bias associated with any family group containing children and a positive offsetting effect, which could either reflect Fogel and Engerman's hypothesized value creation from preserving the nuclear family or an alternative form of selectivity bias attached to the sale of nuclear families.

In cases where there were close family relationships not related to children (captured by the regressor Percent Other Family), sales of siblings or sales of husband and wife, the coefficient is a statistically significant -0.22 . We believe that selectivity bias in the sales of these closely related adult family members remains a likely explanation of our findings - in other words, a married couple, or a sibling pair, were more likely to be sold together if one of them was of lower value than the corresponding stand-alone slave sold.

Group prices with individuals over the age of 50 in family groups were strongly discounted. For example, the sale price of a man and his wife both aged greater than 50 was discounted an additional 74 percent compared to a man and wife both under age 50. An interpretation of this finding is that the value of relatively weak older individuals was especially reduced by being sold in groups, perhaps because those individuals were especially vulnerable to injury or infirmity. Interestingly, and consistent with either positive or negative selectivity, the coefficient on unaffiliated older people is small and not statistically significant, 
indicating that family connections were essential for observing discounts on older individuals in groups. ${ }^{12}$

As a robustness check, because few young children were sold singly, we examined the subset of slave groups that consisted entirely of individuals older than ten years of age. Our findings for this subsample are the same as for the full sample: there are no scale discounts, and family discounts remain large and statistically significant. ${ }^{13}$

\section{Transport Costs as a Potential Source of Selectivity Bias}

For interregional traders, economic profit equaled the difference between the slave's expected price in the delivered market and the sum of transport cost and the slave's purchase price in the exporting area. Because children commanded relatively low market prices, traders may have found that they were less profitable for shipment than other, more valuable, slaves. Consistent with this prediction, relatively few children were imported and sold in New Orleans. Children aged 10 years or less comprised only 10 percent of all imported slaves, whereas children comprised 18 percent of the local slaves (or those of unknown origin). Not only were relatively few imported children sold in New Orleans, many were sold without their mothers. Among children aged 10 years or less, 32 percent of the imported slaves were sold without their mothers, whereas only 24 percent of the local slaves were sold without their mothers. In addition, because mother-child pairings were the most common family group, the paucity of imported children helps to account for the lack of family groups among imported slaves. Only 16 percent of imported slaves were sold in family groups, whereas nearly 29 percent of local slaves were sold in families. Finally, relatively few imported females, aged 20 to 24 years, were sold with a child compared to females of local or unknown origin. ${ }^{14}$ Traders selected relatively few children for shipment to New Orleans, and in many cases, these children were sold without their mothers.

Transportation costs also could have affected the magnitude of the family group discounts. For example, traders may have more rigorously

\footnotetext{
${ }^{12}$ According to Ulrich B. Phillips, an elderly slave was "worth substantially less than nothing, for he would render no service and his master must maintain him indefinitely on a pensioner's dole." As evidence, he cites the example of a buyer offering a higher price for a group of slaves if the seller would retain ten superannuated slaves rather than include them in the sale. An owner, who was obligated to provide care for unproductive slaves, might bundle them with more valuable slaves and offer the group at a discounted price. Phillips, Life and Labor, p. 175.

${ }^{13}$ These regression results are available from the authors on request.

${ }^{14}$ The fact that so many slaves were sold without other family members has been viewed as an indication of selectivity in the sales process. See Fogel and Engerman, Time on the Cross, p. 49; and Tadman, Speculators, p. 152.
} 
selected single individuals for transport to New Orleans as compared to those slaves who were shipped as part of a family. If this effect were important, then even if the familial care motive did not apply, group sales could have displayed discounts relative to stand-alone sales for imported slaves but not necessarily for local slaves.

In equation 6 of Table 2, we investigate whether observed family discounts differ depending on the slave's region of origin. If transport costs, rather than familial care motives, were the source of family discounts, then family discounts would have been greater for imported slaves. Because of sample size limitations, we do not differentiate between children of different ages. We find no evidence that transport cost selectivity caused family discounts. Children imported as members of groups do not display greater discounts than local children sold as members of groups. In fact, for unrelated children sold in groups, estimated discounts are lower for imports than for locals, although the difference between locals and imports is not statistically significant.

\section{Legal Restrictions vs. Family Preferences}

Laws prohibited the division of some family groups into their component parts. There were two sets of relevant legal restrictions. First, with respect to children, according to the Louisiana Black Code, passed in 1806 and enhanced with stiff penalties for violation in 1829, children under the age of ten could not be sold separately from their mothers unless they were orphans. Second, with respect to older people, Section 8 of the Black Code states that: ". . . if at a public sale of slaves, there happen to be some who be disabled through old age or otherwise, and who have children, such slaves shall not be sold but with such of his children whom he or she may think proper to go with." 15 In addition, many states prohibited the emancipation of elderly slaves as a means of preventing masters from abandoning older slaves who were injured or sick in an attempt to get the public to care for them as paupers. ${ }^{16}$

The limitation on the separate sale of children under the age of ten had an effect on the presence of stand-alone sales of slave children. Table 3 reports data on the relative number of children sold without their mothers both before and after the imposition of penalties in 1829

\footnotetext{
${ }^{15}$ Louisiana, Acts Passed, p. 154.

${ }^{16}$ Virginia outlawed the manumission of unsupported slaves aged 45 years and older in 1782 . The law was upheld in 1824 and 1848; Louisiana joined other Southern states in outlawing manumission in 1857, after a rise in emancipations throughout the 1850s. See Savitt, Medicine, p. 203; Schafer, Becoming Free, p. 2; and Klebaner, "American Manumission Laws."
} 
TABLE 3

EFFECT OF 1829 BLACK CODE PENALTIES ON FREQUENCY OF CHILDREN SOLD ON STAND-ALONE BASIS AS "ORPHANS"

The Sale of Orphans in New Orleans, 1810 to 1859

\begin{tabular}{ccc}
\hline & $\begin{array}{c}\text { Slaves Under 10 Years of Age Sold } \\
\text { Separately as Percentage of Slaves } \\
\text { Sold with Mother and Those Sold } \\
\text { Without Mothers }\end{array}$ & $\begin{array}{c}\text { Slaves 10 to 12 Years of Age Sold } \\
\text { Separately as Percentage of Slaves } \\
\text { Sold with Mother and Those Sold } \\
\text { Without Mothers }\end{array}$ \\
\hline $1810-1819$ & 13.5 & 69.7 \\
$1820-1829$ & 14.9 & 78.0 \\
$1830-1839$ & 8.3 & 70.5 \\
$1840-1849$ & 9.8 & 74.3 \\
$1850-1859$ & 5.3 & 63.6 \\
\hline
\end{tabular}

Notes: The Fogel and Engerman sample includes the records of 1,145 children, 0 to 12 years of age (aged under 13 years). We can classify these children three ways: (1) 225 children sold singly, (2) 721 children sold with their mothers, and (3) 199 children sold in a group but without an identified mother. For this latter group, 126 children were not sold with a woman, aged 15 years or more - in other words, without a potential mother. In addition, two more children were classified as orphans. We assume that these 128 children were not sold with their mothers, leaving 71 children who might have been sold with their mother. We assume that these 71 children were sold with their mothers.

Source: Fogel and Engerman, "New Orleans Slave."

for falsely identifying children as orphans. Prior to the law's passage, approximately 14 percent of young children were sold as orphans whereas after 1829 , only 7 percent were sold without their mothers. It is evident from these data that behavior changed after 1829 , and this may be related to the new penalties. ${ }^{17}$

Presumably, the intent of the Louisiana laws was to encourage the preservation of more families than was otherwise profitable to preserve. If the 1829 law was (at least partially) effective in preventing the profitable separation of some mothers and children, then the combined value of the mother-child groups would have been reduced by the law relative to their stand-alone values. Consequently, an effective legal restriction on the separate sale of family members might account for the observed family discount. Donald Sweig argues that slave traders preferred to sell mother-child groups particularly after the passage of the 1829 law. ${ }^{18}$ If traders less rigorously selected these groups, then the sum

\footnotetext{
${ }^{17}$ We test this proposition by combining the first two time periods and the last three and performing a simple Chi-square test. Children aged less than 10 years were significantly less likely to be sold separately after 1829. (Chi-square equals 8.67 (1) - significant at 0.003 level.) For those children aged 10 years or more, there was no significant change. (Chi-square equals 0.908 (1) - significant at .34 level.) Court cases involving the enforcement of the 1829 act typically concerned a buyer attempting to claim ownership of an underage child after the separate purchase of the child's mother. See Schafer, Slavery, pp. 165-68.

${ }^{18}$ Sweig, "Reassessing," p. 11.
} 
of their stand-alone values would have been reduced, thus accounting for the observed family discount.

This price effect could have been mitigated by arbitrage. Legal restrictions might have created a profit opportunity for sellers who were willing and able to evade them. For example, after buying a motherchild pair at a reduced price, a trader might sell them singly in New Orleans, thus reaping a capital gain. To the extent that owners could break the law with impunity, then the effective protection provided to slave families, as well as the magnitude of the observed family discount, would have been reduced. When we allow the discount for related and unrelated children to change in magnitude after 1829 in specification 7, the results indicate that the 1829 law increased the family discount associated with the presence of young children in family groups. The coefficients are larger for groups with young children whether they are identified as family members or not, which further supports the view that affiliated children may have been frequently misidentified as unaffiliated.

\section{DATA FROM SHIP MANIFESTS}

If selectivity bias explains group discounts on slave sales, that implies that the characteristics of stand-alone slaves sold have superior value on average to those of family-related slaves sold in groups with the same set of characteristics observed in our slave sales database. An ideal test of that proposition would require measuring, for stand-alone and familyaffiliated slaves sold in the New Orleans market, relevant observable characteristics that are not included in the slave sales database but that would have been observable to the market.

Height would be one such measure. Taller slaves were assessed at higher prices. ${ }^{19}$ Heights were not recorded in the slave sales database, but ship manifests did record heights for slaves that were shipped to the New Orleans market by slave traders from other parts of the South. ${ }^{20}$ Unfortunately, family affiliations were not recorded in the ship manifests. Nevertheless, we have devised a method for inferring

\footnotetext{
${ }^{19}$ Margo and Steckel, "Heights," p. 531.

${ }^{20}$ In the following, we demonstrate that traders selected slaves for shipment in family groups using observable characteristics that were not recorded on the sale invoices. Because traders may have separated families after debarkation, the families sold in New Orleans, and the corresponding statures of the family members, may have differed from those listed on the coastwise manifests. While it is certainly possible that some slaves shipped as families were later separated prior to sale, it is reasonable to assume that the family groups sold in New Orleans were also shipped as a group. The fact that we observe both group family discounts and lower heights for children shipped with their mothers corroborates that assumption.
} 
(probabilistically) whether or not a child listed on a ship manifest was traveling with his or her mother on the ship.

The coastwise manifests were mandated by Congress in an effort to prevent the smuggling of foreign slaves into the United States. The Abolition Act of 1807 provided for the coastwise transportation of domestic slaves by requiring duplicate manifests for each shipment of slaves. Each manifest lists slaves by (first) name, along with their age, sex, color, and stature, and the names and residences of the shippers. The outward manifest was deposited at the port of embarkation, whereas the inward manifest was deposited at the port of debarkation. We use Richard Steckel's sample of 903 inward coastwise manifests for the port of New Orleans. These manifests list a total of 13,147 slaves.

The coastwise manifests include the records of slave traders and other shippers to New Orleans. In order to identify the manifests belonging to slave traders, Pritchett and Freudenberger compared the names of the shippers listed on the manifests with those of people who sold slaves in New Orleans during the same year. The New Orleans Conveyance Office, which was established by state law in 1827, alphabetized the names of vendors in the city. After consulting approximately 80 volumes in the Conveyance Office, Pritchett and Freudenberger identified 201 manifests and a total of 6,418 slaves where the shipper was a New Orleans slave trader. ${ }^{21}$

We use the order of the slaves listed on the manifests to identify likely family (mother and child) relationships. By convention, children who were shipped with their mothers were listed directly below their mothers on the manifests. ${ }^{22}$ We infer family status by the presence of a female of childbearing age immediately followed by a child. To be specific, we classify all female slaves, aged 15 years or more, as potential mothers. If she is immediately followed on the manifest by a slave who is 15 to 44 years younger than herself, we identify the slave as her child. Because some mothers were shipped with more than one child, we follow a similar procedure for the next slave listed on the manifest - if the immediate preceding slave is identified as having a mother, and the slave is between 15 and 44 years younger than the potential mother, we identify the slave as her child. We continue this procedure, allowing for a maximum number of eight children being shipped with one particular mother.

Our sample includes the records of 910 children, aged 4 to 13 years, listed on the manifests of identified New Orleans slave traders. Using

\footnotetext{
${ }^{21}$ Pritchett and Freudenberger, "Peculiar Sample," p. 115. Because we include the manifests of shipments prior to 1827 , our sample is slightly larger than theirs.

${ }^{22}$ Sweig, "Reassessing the Human Dimension," p. 8.
} 
the method described previously, we estimate that 675 children, or 74 percent of the children shipped by traders, were not shipped with their mothers. The prevalence of these unaffiliated children varied by age. For young children, aged 4 or 5 years, less than 25 percent were identified as orphans. For children aged 10 to 13 years, however, over 88 percent were shipped without their mothers. Interestingly, a similar pattern is also found for the children sold in New Orleans-less than 8 percent of young children, aged 4 or 5 years, were sold without their mothers. In contrast, over 75 percent of the children aged 10 to 13 years were unaffiliated. For both samples, older children were much more likely to be unaffiliated than the younger children. The similarity between these two samples adds credence to our method for identifying children shipped with their mothers.

\section{HEIGHTS REGRESSIONS MEASURING SELECTIVITY BIAS}

In Table 4, we report regression results that compare the heights of children that we identify as affiliated with a mother versus those that are not affiliated, controlling for age and sex. The first regression indicates that the children that we identify as (likely to have been) shipped with their mothers are 1.26 inches shorter than children of the same sex and age who are unaffiliated. The second regression in Table 4 interacts the "shipped with mother" effect on height with age indicators for children in two age groups: (1) children aged four to ten years, and (2) children aged more than 10 years. We find that for children aged ten years or less, the estimated height shortfall of affiliated children is roughly 1.47 inches. The estimated height shortfall for older affiliated children is 0.78 inches, although imprecisely estimated. Therefore, the results are consistent with the selectivity-bias hypothesis that children shipped to New Orleans for sale with their mothers were shorter and thus less valuable than children shipped without their mothers. The estimated effect is stronger for young children, although the difference between younger and older children is not robustly statistically significant. This finding lends support to the selectivity bias hypothesis for explaining the observed discounts associated with children in family groups, reported in Table 2.

As shown in Table 2, the magnitude of the family group discount associated with the sale of young children increased after 1829, when 
TABLE 4

HEIGHTS OF CHILDREN, AGED 4 TO 13 YEARS, SHIPPED BY NEW ORLEANS SLAVE TRADERS ORDINARY LEAST SQUARES REGRESSION RESULTS

\begin{tabular}{|c|c|c|c|c|}
\hline Covariate & (1) & (2) & (3) & $\begin{array}{l}\text { Mean and } \\
\text { Std. Dev. }\end{array}$ \\
\hline Intercept & $\begin{array}{l}37.79 \\
(0.65)\end{array}$ & $\begin{array}{l}37.96 \\
(0.67)\end{array}$ & $\begin{array}{l}38.02 \\
(0.67)\end{array}$ & 1 \\
\hline Male $(1=$ yes, $0=$ no $)$ & $\begin{array}{c}0.25 \\
(0.94)\end{array}$ & $\begin{array}{l}0.25 \\
(0.94)\end{array}$ & $\begin{array}{c}0.13 \\
(0.94)\end{array}$ & $\begin{array}{c}0.485 \\
(0.500)\end{array}$ \\
\hline Age $5(1=$ yes, $0=$ no $)$ & $\begin{array}{l}2.92 * \\
(0.83)\end{array}$ & $\begin{array}{l}2.91 * \\
(0.83)\end{array}$ & $\begin{array}{l}3.05^{*} \\
(0.83)\end{array}$ & $\begin{array}{c}0.062 \\
(0.240)\end{array}$ \\
\hline Age $6(1=$ yes, $0=$ no $)$ & $\begin{array}{l}5.31^{*} \\
(1.05)\end{array}$ & $\begin{array}{l}5.25^{*} \\
(1.05)\end{array}$ & $\begin{array}{l}5.24^{*} \\
(1.05)\end{array}$ & $\begin{array}{c}0.044 \\
(0.205)\end{array}$ \\
\hline Age $7(1=$ yes, $0=$ no $)$ & $\begin{array}{l}8.88^{*} \\
(0.91)\end{array}$ & $\begin{array}{l}8.81 * \\
(0.91)\end{array}$ & $\begin{array}{l}8.68^{*} \\
(0.91)\end{array}$ & $\begin{array}{c}0.060 \\
(0.238)\end{array}$ \\
\hline Age $8(1=$ yes, $0=$ no $)$ & $\begin{array}{l}9.67^{*} \\
(0.82)\end{array}$ & $\begin{array}{l}9.54^{*} \\
(0.83)\end{array}$ & $\begin{array}{l}9.48^{*} \\
(0.83)\end{array}$ & $\begin{array}{l}0.096 \\
(0.294)\end{array}$ \\
\hline Age $9(1=$ yes, $0=$ no $)$ & $\begin{array}{l}11.43^{*} \\
(0.81)\end{array}$ & $\begin{array}{l}11.31 * \\
(0.82)\end{array}$ & $\begin{array}{l}11.33^{*} \\
(0.82)\end{array}$ & $\begin{array}{c}0.093 \\
(0.291)\end{array}$ \\
\hline Age $10(1=$ yes, $0=$ no $)$ & $\begin{array}{l}14.12^{*} \\
(0.79)\end{array}$ & $\begin{array}{l}13.99 * \\
(0.80)\end{array}$ & $\begin{array}{l}13.91 * \\
(0.80)\end{array}$ & $\begin{array}{c}0.132 \\
(0.339)\end{array}$ \\
\hline Age $11(1=$ yes, $0=$ no $)$ & $\begin{array}{l}15.75^{*} \\
(0.83)\end{array}$ & $\begin{array}{l}15.53^{*} \\
(0.85)\end{array}$ & $\begin{array}{l}15.47^{*} \\
(0.85)\end{array}$ & $\begin{array}{c}0.112 \\
(0.316)\end{array}$ \\
\hline Age $12(1=$ yes, $0=$ no $)$ & $\begin{array}{l}16.78^{*} \\
(0.74)\end{array}$ & $\begin{array}{l}16.54^{*} \\
(0.77)\end{array}$ & $\begin{array}{l}16.47^{*} \\
(0.77)\end{array}$ & $\begin{array}{c}0.188 \\
(0.391)\end{array}$ \\
\hline Age $13(1=$ yes, $0=$ no $)$ & $\begin{array}{l}19.08^{*} \\
(0.76)\end{array}$ & $\begin{array}{l}18.84^{*} \\
(0.80)\end{array}$ & $\begin{array}{l}18.77^{*} \\
(0.80)\end{array}$ & $\begin{array}{c}0.151 \\
(0.358)\end{array}$ \\
\hline $\begin{array}{l}\text { Shipped with mother } \\
\quad(1=\text { yes, } 0=\text { no })\end{array}$ & $\begin{array}{l}-1.26^{*} \\
(0.31)\end{array}$ & & & $\begin{array}{c}0.258 \\
(0.438)\end{array}$ \\
\hline $\begin{array}{l}\text { Shipped with mother and aged } 4 \\
\text { to } 10 \text { years }(1=\text { yes, } 0=\text { no })\end{array}$ & & $\begin{array}{l}-1.47^{*} \\
(0.37)\end{array}$ & & $\begin{array}{l}0.207 \\
(0.405)\end{array}$ \\
\hline $\begin{array}{l}\text { Shipped with mother and older } \\
\text { than } 10 \text { years }(1=\text { yes, } 0=\text { no })\end{array}$ & & $\begin{array}{l}-0.78 \\
(0.55)\end{array}$ & & $\begin{array}{c}0.052 \\
(0.221)\end{array}$ \\
\hline $\begin{array}{l}\text { Shipped prior to April } 1829 \text {, with } \\
\text { mother, and aged } 4 \text { to } 10 \text { years } \\
(1=\text { yes, } 0=\text { no })\end{array}$ & & & $\begin{array}{l}-0.80^{*} \\
(0.49)\end{array}$ & $\begin{array}{c}0.082 \\
(0.275)\end{array}$ \\
\hline $\begin{array}{l}\text { Shipped prior to April } 1829 \text {, with } \\
\text { mother, and older than } 10 \text { years } \\
(1=\text { yes, } 0=\text { no })\end{array}$ & & & $\begin{array}{l}-0.38 \\
(0.83)\end{array}$ & $\begin{array}{c}0.021 \\
(0.143)\end{array}$ \\
\hline $\begin{array}{l}\text { Shipped after April } 1829 \text {, with } \\
\text { mother, and aged } 4 \text { to } 10 \text { years } \\
(1=\text { yes, } 0=\text { no })\end{array}$ & & & $\begin{array}{l}-1.95^{*} \\
(0.43)\end{array}$ & $\begin{array}{c}0.124 \\
(0.330)\end{array}$ \\
\hline $\begin{array}{l}\text { Shipped after April } 1829 \text {, with } \\
\text { mother, and older than } 10 \text { years } \\
(1=\text { yes, } 0=\text { no })\end{array}$ & & & $\begin{array}{l}-1.05 \\
(0.69)\end{array}$ & $\begin{array}{c}0.031 \\
(0.173)\end{array}$ \\
\hline $\begin{array}{l}\text { Number of children } \\
\text { Adjusted } R^{2}\end{array}$ & $\begin{array}{c}910 \\
0.730\end{array}$ & $\begin{array}{c}910 \\
0.730\end{array}$ & $\begin{array}{c}910 \\
0.731\end{array}$ & 910 \\
\hline
\end{tabular}

* indicates the covariate is significantly different from zero at the 10 percent level.

Notes: The dependent variable is the height of slaves in inches. The omitted variable represents a female slave, aged four years, shipped without her mother. Regression results for interactions of age and male indicator variables are not reported. Sample includes 120 manifests of slave traders identified from the New Orleans Conveyance Records. For the identification of children sold with mothers, see the text. Standard errors are listed in parentheses beneath regression coefficients.

Source: Inward coastwise manifests, New Orleans, LA. 
Louisiana law required all children under age 10 to be sold with their mothers. The third regression in Table 4 shows that the average heights of children traveling with their mothers after the passage of the 1829 law were lower, consistent with the increased price discount found in Table 2.

In Table 5, we report additional results including manifests for ships unrelated to the slave trade. These data serve two purposes. First, they provide a control group to test whether height differences measured in Table 4 between affiliated and unaffiliated children being sold can be properly attributed to the effects of selectivity bias in the sale of affiliated children sold with their mothers relative to stand-alone slave sales. If the same result were observed in manifest data unrelated to the slave trade, then that would suggest some other causal factor for this difference unrelated to selectivity bias in slave sales. Table 5 shows that the "shipped with mother effect," per se, is zero. The covariate omitted from the regression equations refers to children shipped by non-traders and without an identified mother. As indicated by the regression coefficient for "Shipped with mother," the heights of child slaves traveling on non-slave trader ships had similar heights irrespective of whether they were traveling with their mothers. In this larger sample, the indicator variables associated with slave trader vessels continue to show greater heights for children traveling without their mothers, especially for those under the age of 10 years.

A second purpose for analyzing height data from manifests is to compare the slave heights on slave traders' vessels with those traveling in the general population. Here the key finding is that slave children traveling on slave traders' ships, whether with their mothers or alone, were taller on average than slave children traveling on non-slave trader vessels. The magnitudes of the height differences for both child groups traveling on slave traders' vessels are large and statistically significant for slave children under the age of 10 , although the magnitude of the effect is smaller and not statistically significant for children older than 10 who are traveling on a slave trader's ship with their mothers. We interpret this as evidence in favor of positive selectivity related to transportation cost, which caused the heights even of affiliated children en route for sale in New Orleans to be greater than the mean of the general population (as proxied by the average of children's heights from the non-slave trader manifests). 
TABLE 5

HEIGHTS OF CHILDREN, AGED 4 TO 13 YEARS, SHIPPED BY TRADERS AND NONTRADERS, REGRESSION RESULTS

\begin{tabular}{|c|c|c|c|c|}
\hline Covariate & (1) & (2) & (3) & $\begin{array}{l}\text { Mean and } \\
\text { Std. Dev. }\end{array}$ \\
\hline Intercept & $\begin{array}{c}35.37 \\
(0.55)\end{array}$ & $\begin{array}{c}35.25 \\
(0.56)\end{array}$ & $\begin{array}{c}35.29 \\
(0.55)\end{array}$ & 1.000 \\
\hline Male $(1=$ yes, $0=$ no $)$ & $\begin{array}{l}1.30^{*} \\
(0.77)\end{array}$ & $\begin{array}{l}1.31^{*} \\
(0.77)\end{array}$ & $\begin{array}{c}1.24 \\
(0.77)\end{array}$ & $\begin{array}{c}0.490 \\
(0.500)\end{array}$ \\
\hline Age $5(1=$ yes, $0=$ no $)$ & $\begin{array}{c}3.47^{*} \\
(0.74)\end{array}$ & $\begin{array}{c}3.43^{*} \\
(0.74)\end{array}$ & $\begin{array}{c}3.54^{*} \\
(0.74)\end{array}$ & $\begin{array}{c}0.059 \\
(0.236)\end{array}$ \\
\hline Age $6(1=$ yes, $0=$ no $)$ & $\begin{array}{c}4.07 * \\
(0.75)\end{array}$ & $\begin{array}{c}4.07 * \\
(0.75)\end{array}$ & $\begin{array}{c}4.05^{*} \\
(0.75)\end{array}$ & $\begin{array}{c}0.063 \\
(0.243)\end{array}$ \\
\hline Age $7(1=$ yes, $0=$ no $)$ & $\begin{array}{c}8.33^{*} \\
(0.71)\end{array}$ & $\begin{array}{c}8.30 * \\
(0.71)\end{array}$ & $\begin{array}{l}8.24 * \\
(0.71)\end{array}$ & $\begin{array}{c}0.074 \\
(0.262)\end{array}$ \\
\hline Age $8(1=$ yes, $0=$ no $)$ & $\begin{array}{l}10.11^{*} \\
(0.68)\end{array}$ & $\begin{array}{l}10.00 * \\
(0.68)\end{array}$ & $\begin{array}{l}9.97 * \\
(0.68)\end{array}$ & $\begin{array}{c}0.096 \\
(0.295)\end{array}$ \\
\hline Age $9(1=$ yes, $0=$ no $)$ & $\begin{array}{l}12.30^{*} \\
(0.69)\end{array}$ & $\begin{array}{l}12.19^{*} \\
(0.69)\end{array}$ & $\begin{array}{l}12.20^{*} \\
(0.69)\end{array}$ & $\begin{array}{c}0.094 \\
(0.293)\end{array}$ \\
\hline Age $10(1=$ yes, $0=$ no $)$ & $\begin{array}{l}14.33^{*} \\
(0.65)\end{array}$ & $\begin{array}{l}14.23 * \\
(0.65)\end{array}$ & $\begin{array}{l}14.18^{*} \\
(0.65)\end{array}$ & $\begin{array}{c}0.138 \\
(0.345)\end{array}$ \\
\hline Age $11(1=$ yes, $0=$ no $)$ & $\begin{array}{l}16.66^{*} \\
(0.68)\end{array}$ & $\begin{array}{l}17.02 * \\
(0.72)\end{array}$ & $\begin{array}{l}16.98 * \\
(0.72)\end{array}$ & $\begin{array}{c}0.105 \\
(0.306)\end{array}$ \\
\hline Age $12(1=$ yes, $0=$ no $)$ & $\begin{array}{l}17.09^{*} \\
(0.63)\end{array}$ & $\begin{array}{l}17.51 * \\
(0.69)\end{array}$ & $\begin{array}{l}17.47 * \\
(0.69)\end{array}$ & $\begin{array}{c}0.164 \\
(0.370)\end{array}$ \\
\hline Age $13(1=$ yes, $0=$ no $)$ & $\begin{array}{l}19.96^{*} \\
(0.64)\end{array}$ & $\begin{array}{l}20.31 * \\
(0.68)\end{array}$ & $\begin{array}{c}20.27 * \\
(0.68)\end{array}$ & $\begin{array}{c}0.141 \\
(0.348)\end{array}$ \\
\hline $\begin{array}{l}\text { Shipped with mother and not by a trader } \\
\qquad(1=\text { yes, } 0=\text { no })\end{array}$ & $\begin{array}{l}-0.18 \\
(0.34)\end{array}$ & $\begin{array}{l}-0.11 \\
(0.34)\end{array}$ & $\begin{array}{l}-0.11 \\
(0.34)\end{array}$ & $\begin{array}{c}0.130 \\
(0.336)\end{array}$ \\
\hline $\begin{array}{l}\text { Shipped by trader and without mother } \\
\quad(1=\text { yes, } 0=\text { no })\end{array}$ & $\begin{array}{l}1.74^{*} \\
(0.24)\end{array}$ & & & $\begin{array}{c}0.434 \\
(0.496)\end{array}$ \\
\hline $\begin{array}{l}\text { Shipped by trader and with mother } \\
\qquad(1=\text { yes, } 0=\text { no })\end{array}$ & $\begin{array}{c}0.74^{*} \\
(0.33)\end{array}$ & & & $\begin{array}{c}0.151 \\
(0.358)\end{array}$ \\
\hline $\begin{array}{l}\text { Shipped by trader, without mother, } \\
\text { and aged } 4 \text { to } 10 \text { years }(1=\text { yes, } 0=\text { no })\end{array}$ & & $\begin{array}{l}2.17 * \\
(0.32)\end{array}$ & $\begin{array}{l}2.17 * \\
(0.32)\end{array}$ & $\begin{array}{c}0.200 \\
(0.400)\end{array}$ \\
\hline $\begin{array}{l}\text { Shipped by slave trader, without mother, } \\
\text { and older than } 10 \text { years }(1=\text { yes, } 0=\text { no })\end{array}$ & & $\begin{array}{l}1.28^{*} \\
(0.34)\end{array}$ & $\begin{array}{l}1.28^{*} \\
(0.34)\end{array}$ & $\begin{array}{c}0.233 \\
(0.423)\end{array}$ \\
\hline $\begin{array}{l}\text { Shipped by trader, with mother and aged } 4 \\
\text { to } 10 \text { years }(1=\text { yes, } 0=\text { no })\end{array}$ & & $\begin{array}{l}0.86^{*} \\
(0.38)\end{array}$ & & $\begin{array}{c}0.121 \\
(0.326)\end{array}$ \\
\hline $\begin{array}{l}\text { Shipped by trader, with mother and older } \\
\text { than } 10 \text { years }(1=\text { yes, } 0=\text { no })\end{array}$ & & $\begin{array}{c}0.65 \\
(0.63)\end{array}$ & & $\begin{array}{c}0.030 \\
(0.171)\end{array}$ \\
\hline $\begin{array}{l}\text { Shipped by trader prior to April } 1829 \text {, } \\
\text { with mother and aged } 4 \text { to } 10 \text { years } \\
(1=\text { yes, } 0=\text { no })\end{array}$ & & & $\begin{array}{c}1.54 * \\
(0.51)\end{array}$ & $\begin{array}{c}0.048 \\
(0.214)\end{array}$ \\
\hline $\begin{array}{l}\text { Shipped by trader prior to April } 1829 \text {, } \\
\text { with mother and older than } 10 \text { years } \\
(1=\text { yes, } 0=\text { no })\end{array}$ & & & $\begin{array}{l}1.12 \\
(0.94)\end{array}$ & $\begin{array}{c}0.012 \\
(0.110)\end{array}$ \\
\hline
\end{tabular}


TABLE $5-$ continued

\begin{tabular}{|c|c|c|c|c|}
\hline Covariate & (1) & (2) & (3) & $\begin{array}{l}\text { Mean and } \\
\text { Std. Dev. }\end{array}$ \\
\hline $\begin{array}{l}\text { Shipped by trader after April } 1829 \text {, } \\
\text { with mother and aged } 4 \text { to } 10 \text { years } \\
(1=\text { yes, } 0=\text { no })\end{array}$ & & & $\begin{array}{c}0.38 \\
(0.45)\end{array}$ & $\begin{array}{c}0.073 \\
(0.260)\end{array}$ \\
\hline $\begin{array}{l}\text { Shipped by trader after April } 1829 \text {, } \\
\text { with mother and older than } 10 \text { years } \\
(1=\text { yes, } 0=\text { no })\end{array}$ & & & $\begin{array}{c}0.33 \\
(0.78)\end{array}$ & $\begin{array}{c}0.018 \\
(0.133)\end{array}$ \\
\hline Number of children & 1557 & 1557 & 1557 & 1557 \\
\hline Adjusted $R^{2}$ & 0.707 & 0.708 & 0.708 & \\
\hline \multicolumn{5}{|c|}{$\begin{array}{l}\text { * indicates the covariate is significantly different from zero at the } 5 \text { percent level. } \\
\text { Notes: The dependent variable is the height of slaves in inches. The omitted variable represents a } \\
\text { female slave, aged four years, shipped without her mother by someone other than a slave trader. } \\
\text { Regression results for interactions of age and male indicator variables are not reported. Sample } \\
\text { includes } 274 \text { manifests, slave traders identified from the New Orleans Conveyance Records. } \\
\text { For the identification of children sold with mothers, see the text. Standard errors are listed in } \\
\text { parentheses beneath regression coefficients. } \\
\text { Source: Inward coastwise manifests, New Orleans, LA. }\end{array}$} \\
\hline
\end{tabular}

Finally, we estimate the average heights of children traveling with their mothers (and shipped by slave traders) both before and after the passage of the 1829 law. Earlier, we found the increased legal protection of the mother-child relationship was associated with a decrease in the average height of children in such groups. In the third regression of Table 5, the affiliated children shipped by slave traders again were taller prior to the passage of this law. In contrast, the affiliated children shipped by traders after 1829 were on average only slightly taller (approximately .3 inches) than the children shipped by non-traders and the height difference was not statistically significant. The similarity in the heights of these affiliated children suggests that after the passage of this law, traders did not rigorously select these family groups and that only the children shipped separately were unusually tall for their age.

\section{CONCLUSION}

The existence of price discounts for slave families, when compared to stand-alone sales of slaves, has been known for some time. ${ }^{23}$ Previous research attributes this price discount to a reduction in transaction costs associated with group sales. We find, however, no evidence of scale discounts for unrelated slaves. Families, rather than groups, account for the presence of price discounts.

\footnotetext{
${ }^{23}$ Kotlikoff, "Quantitative Description.”
} 
Absent selectivity bias, slaves sold in family groups should have commanded higher prices. Fogel and Engerman argue that owners received economic value from maintaining families, which should have created a price premium rather than a price discount. Our primary explanation for the observed price discount for family groups, based on unobserved heterogeneity, suggests that the family members, if sold singly, would have commanded lower market prices than the unrelated slaves who were not sold in family groups. If the members of intact families had less valuable unobserved characteristics (such as shorter stature or poor health), this could explain why the group price is lower on average than the sum of the predicted prices for the individual family members when sold singly.

In order to test for the presence of unobserved heterogeneity, we searched for additional evidence that slaves sold in family groups were adversely selected. The coastwise manifests list the heights of slaves intended for sale in New Orleans. By comparing the heights of slaves (we infer were) shipped in family groups with those of slaves shipped separately, we demonstrate that children shipped with their mothers had shorter stature on average than children shipped singly. Because height is correlated with market value, the shorter stature of family slaves may account for the observed price discount observed for families.

The empirical literature on slave family discounts began with Fogel and Engerman's hypothesis that slave family sales should entail a premium, owing to the value of maintaining family ties, which they argued would be reflected in the values of slaves to their masters. ${ }^{24}$ While our article does find some limited support for the existence of a nuclear family premium, ironically, we think our evidence of more general family discounts may provide stronger evidence of a positive price effect from preserving family ties. In our view, family discounts reflect the fact that the market attaches value to keeping some families together, especially in circumstances where one family member is weak or needy. That market decision itself depended on preexisting slave family preferences for family ties, which were only selectively permitted by the market.

\footnotetext{
${ }^{24}$ Fogel and Engerman, Time on the Cross.
} 


\section{REFERENCES}

Advertiser [New Orleans], 23 September 1830.

Alchian, Armen A., and William R. Allen. Exchange and Production: Theory in Use. Belmont, CA: Wadsworth Publishing, 1969.

Choo, Eugene, and Jean Eid. "Interregional Price Difference in the New Orleans Auctions Market for Slaves.” Journal of Business \& Economic Statistics 26, no. 4 (2008): 486-509.

Courier [New Orleans], 24 September 1830.

Fogel, Robert W., and Stanley Engerman. Time on the Cross: Evidence and Methods. Boston: Little, Brown and Company, 1974.

. Time on the Cross: The Economics of American Negro Slavery. Boston: Little, Brown and Company, 1974.

."The New Orleans Slave Sale Sample, 1804-1862 [Computer File]." ICPSR

Study No. 7423. Ann Arbor, MI: Inter-university Consortium for Political and Social Research [distributor], 1976.

. "Some Notes on the Apparent Aversion to the Separate Sale of Children Under Age Ten in the New Orleans Slave Market." In Without Consent or Contract: Evidence and Methods, edited by Robert W. Fogel, Ralph A. Galatine, and Richard L. Manning, 256-59. New York: W. W. Norton, 1992.

Freudenberger, Herman, and Jonathan B. Pritchett. "The Domestic United States Slave Trade, New Evidence.” Journal of Interdisciplinary History 21, no. 3 (1991): 447-77.

Greene, William H. Econometric Analysis. Englewild Cliffs, NJ: Prentice Hall, 1993.

Greenwald, Bruce, and Robert Glasspiegel. "Adverse Selection in the Market for Slaves: New Orleans, 1830-1860." Quarterly Journal of Economics 98, no. 3 (1983): 479-99.

Klebaner, Benjamin J. "American Manumission Laws and the Responsibility for Supporting Slaves." Virginia Magazine of History and Biography 63, no. 4 (1955): 443-53.

Kotlikoff, Laurence. "The Structure of Slave Prices in New Orleans, 1804 to 1862." Economic Inquiry 17, no. 4 (1979): 496-517.

. "Quantitative Description of the New Orleans Slave Market, 1804 to 1862."

In Without Consent or Contract: Markets and Production, Technical Papers, Vol. 1, edited by Robert W. Fogel and Stanley L. Engerman, 31-53. New York: W. W. Norton, 1992.

Louisiana. Acts Passed at the First Session of the First Legislature of the Territory of Orleans. New Orleans: Bradford \& Anderson, 1806.

Margo, Robert A., and Richard H. Steckel. "The Heights of American Slaves: New Evidence on Slave Nutrition and Health." Social Science History 6, no. 4 (1982): 515-38.

New Orleans Notarial Archives. New Orleans, LA.

Phillips, Ulrich B. Life and Labor in the Old South. Boston: Little, Brown and Company, 1929.

Pritchett, Jonathan B. "The Interregional Slave Trade and the Selection of Slaves for the New Orleans Market." Journal of Interdisciplinary History 28, no. 3 (1997): 57-85.

Pritchett, Jonathan B., and Richard M. Chamberlain. "Selection in the Market for Slaves: New Orleans, 1830-1860." Quarterly Journal of Economics 108, no. 2 (1993): 461-73. 
Pritchett, Jonathan B., and Herman Freudenberger. "A Peculiar Sample: The Selection of Slaves for the New Orleans Market." This JourNAL 52, no. 1 (1992): 109-27.

Savitt, Todd L. Medicine and Slavery: The Diseases and Health Care of Blacks in Antebellum Virginia. Urbana: University of Illinois Press, 1978.

Schafer, Judith Kelleher. Slavery, the Civil Law, and the Supreme Court of Louisiana. Baton Rouge: Louisiana State University Press, 1994.

. Becoming Free, Remaining Free: Manumission and Enslavement in New Orleans, 1846-1862. Baton Rouge: Louisiana State University Press, 2003.

Sweig, Donald M. "Reassessing the Human Dimension of the Interstate Slave Trade." Prologue 12, no. 1 (1980): 4-19.

Tadman, Michael. Speculators and Slaves: Masters, Traders, and Slave in the Old South. Madison: University of Wisconsin Press, 1989. 